\title{
Taxonomic review of the genus Catoclastus from Peru (Coleoptera: Scarabaeidae: Rutelinae)
}

\author{
José MONDACA ${ }^{1)} \&$ Matthias SEIDEL ${ }^{2,3)}$ \\ 1) Servicio Agrícola y Ganadero (SAG), Camino La Pólvora Km 12, Valparaíso, Chile; e-mail: jose.mondaca@sag.gob.cl \\ 2) Department of Entomology, National Museum, Cirkusová 1740, CZ-19300, Prague, Czech Republic; e-mail: matth.seidel@gmail.com. \\ ${ }^{3)}$ Zentralmagazin Naturwissenschaftlicher Sammlungen, Martin-Luther-Universität Halle-Wittenberg, Domplatz 4, Halle (Saale), D-06108, Germany
}

Accepted:

$18^{\text {th }}$ December 2019

Published online:

$27^{\text {th }}$ December 2019

\begin{abstract}
Catoclastus Solier, 1851 (Coleoptera: Scarabaeidae: Rutelinae: Rutelini), a genus endemic to Peru, is revised. Based on morphology and examination of type specimens, Catoclastus jaumesi Soula, 2010 is a new synonym of C. chevrolatii Solier, 1851, while Catoclastus rabinovichi Martínez, 1971 is transferred to the genus Mecopelidnota Bates, 1904, leading to Mecopelidnota rabinovichi (Martínez) as a new combination. Characters that characterize the genus, natural history, and distribution data are given. Implications and problems associated with intraspecific variability of $C$. chevrolatii are discussed. As a result of our research, the genus is considered monotypic and endemic to western Peru.
\end{abstract}

Key words. Coleoptera, Scarabaeidae, Rutelinae, Catoclastus, Mecopelidnota, new synonym, new combination, intraspecific variation, Peru, Neotropical Region

Zoobank: http://zoobank.org/urn:lsid:zoobank.org:pub:E1EE6D56-D9E5-4EDD-B3F7-D99D8DD15035

(C) 2019 The Authors. This work is licensed under the Creative Commons Attribution-NonCommercial-NoDerivs 3.0 Licence.

\section{Introduction}

Catoclastus Solier, 1851 is a little known genus of Rutelini that includes three species (RATCLIFFE et al. 2015, MOore et al. 2017). It was originally described on the basis of the type species Catoclastus chevrolatii Solier from Chile (SOLIER 1851), a distributional record now considered erroneous (Moore et al. 2017). The second species added to the genus, Catoclastus rabinovichi, was described by MarTínez (1971) from Cusco, Peru. Soula (2010) designated the neotype of C. chevrolatii and described Catoclastus jaumesi as a third Peruvian species, but made no mention of C. rabinovichi.

Catoclastus species are moderate in size (16-24 mm), elongate oval, metallic green with reddish-brown legs (Figs $2 \mathrm{~A}-\mathrm{C}, \mathrm{F}-\mathrm{H}$ ), and rarely collected. In many respects, species in the genus are similar to Pelidnota MacLeay, 1819 species with rugose elytra (e.g., P. osculatii Guérin-Méneville, 1855, P. pennata Ohaus, 1912, P. granulata (Gory, 1834), among others). The purpose of this paper is to provide a review of genus, including redescriptions, diagnoses, and images of type specimens. As a result of our research, the genus Catoclastus includes only C. chevrolatii, which is a highly variable species endemic to Peru.

\section{Material and methods}

Seventeen specimens of Catoclastus (including all primary types) were studied for this revision, from the following institutional and private collections:

BMNH The Natural History Museum, London, United Kingdom (Maxwell Barclay, Beulah Garner);

CCECL Musée des Confluences, Lyon, France (Cédric Audibert);

MACN Museo Argentino de Ciencias Naturales "Bernardino Rivadavia," Buenos Aires, Argentina (Arturo Roig Alsina);

MNHN Muséum National d'Histoire Naturelle, Paris, France (Olivier Montreuil);

MSPC Matthias Seidel personal collection, Prague, Czech Republic;

MUSM Museo de Historia Natural de la Universidad de San Marcos, Lima, Peru (Luis Figueroa);

USNM United States National Museum, Washington, District of Columbia, United States of America (currently housed at the University of Nebraska State Museum, Lincoln, Nebraska, United States of America for off-site enhancement) (Brett Ratcliffe, Floyd Shockley).

VMDC Víctor Manuel Diéguez collection, Santiago, Chile.

Redescriptions are based on analyses of external morphological characters and male genitalia. All specimens were examined, dissected, and illustrated using a stereomicroscope Olympus SZ61 (10-60×). Male genitalia and mouthparts were extracted by relaxing the specimens in hot 
water and then glued on cardboard for photographing and illustrating. Photographs were taken by a Canon DCM510 camera. Illustrations of the parameres of the aedeagus were prepared from photographs using the program Inkscape version 0.92.4.

The following definitions and standards were used in the descriptions and diagnoses: Color is based on dried, pinned specimens. Body length was measured dorsally along the midline, from the apex of the clypeus to the apex of the elytra. Body width was measured at the widest point, typically at the middle of the elytra. Puncture density was defined as dense if punctures are nearly confluent to less than two puncture diameters apart, moderately dense if punctures are between two to six puncture diameters apart, and sparse if punctures are separated by more than six puncture diameters. Puncture size was defined as small if punctures were $0.02 \mathrm{~mm}$ or smaller, moderate if $0.02-0.07 \mathrm{~mm}$, and large if $0.07 \mathrm{~mm}$ or larger. Setae were defined as sparse if there were few setae, moderately dense if the surface was visible but with many setae, and dense if the surface was obscured by setae. For the description of the morphological structures, we follow the terminology proposed by MOORE et al. (2017) and SeIDEL et al. (2017).

Label data are quoted verbatim between ("). A single slash (/) indicates a break between lines on the same label, and lower case letters (a, b, c) indicate different labels. Geographic coordinates of the collecting sites where recorded using a Google Earth Pro. The distribution map (Fig. 3) was generated by entering the geographical coordinates on the website www.simplemappr.net.

\section{Taxonomy}

\section{Genus Catoclastus Solier, 1851 \\ (Figs 1A-J, 2A-I)}

Catoclastus Solier, 1851: 95 (original description); LaCoRdaIRE (1855): 363 (catalog); HAROLD (1869): 1226 (catalog); ReED (1876): 287 (cata$\log$ ); Pнilıрі (1887): 691 (catalog); Онаus (1918): 21 (catalog); Онаus (1934): 72-74 (catalog); OHAUs (1952): 2 (checklist); BLACKWELDER (1944): 236 (checklist); MaсhatschKe (1972): 20 (checklist); Soula (2010): 3 (revision); KRAJCIK (2012): 66 (checklist); RATCLIFFE et al. (2015): 199 (checklist); Moore et al. (2017): 57 (catalog).

Type species. Catoclastus chevrolatii Solier, 1851, by monotypy.

Redescription. $\mathrm{N}=8$ males; 9 females. Elongate oval, widest at posterior half (Figs $2 \mathrm{~A}-\mathrm{B}, \mathrm{F}-\mathrm{H}$ ). Body length 16.0-18.9 mm (ठ), 20.0-24.0 mm ( (); width 7.6-9.0 mm (ठ), 10.0-12.0 mm (ठ)

Color. Dorsal surface green metallic, venter green coppery, legs reddish brown.

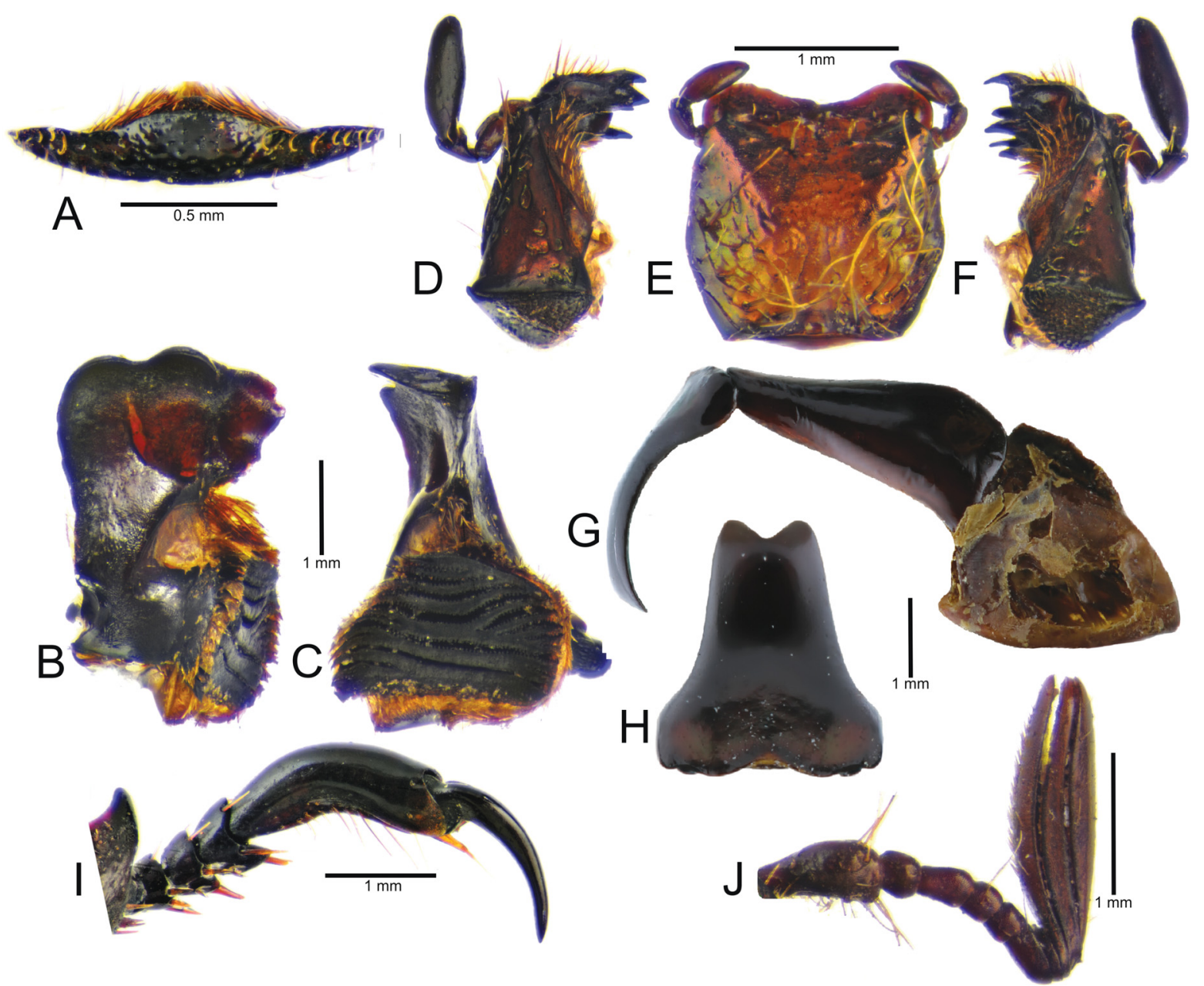

Fig. 1. Detailed morphology of the genus Catoclastus Solier, 1851. A - labrum, frontal view; B-C - left mandible, dorsal and lateral view; D, F - left and right maxilla, lateral view; E - mentum, ventral view; G-H - aedeagus, lateral and caudal view; I - protarsus of male, lateral view; J - antenna. 
Head. Subtrapezoidal shape; disc of clypeus and frons slightly convex (lateral view). Frons and clypeus densely punctate, punctures small to moderate in size; frontoclypeal suture not impressed. Eyes small, rounded, interocular width 4.7 transverse eye diameters, ventrally globose; eye canthus flattened, not cariniform. Clypeus rounded or truncate distally, with margins not reflexed, lacking bead; dorsal surface irregular, with tegument elevated at apex and disc, and depressed at sides. Mandibles exposed beyond clypeal margin, with apex bidentate with two large, rounded, reflexed teeth (Figs 1B, 2A-B, F-G); molar area wider than long, with surface strongly striate (Figs 1B-C). Labrum medially with apex deeply emarginate (Fig. 1A). Maxilla with six teeth; galea not fused, with moderately long setae (Figs 1D, F). Labium hexagonal to semicircular in shape, apex emarginated, concave in anterior half (Fig. 1E). Antenna with 10 antennomeres, apical three antennomeres forming club; club longer than antennomeres II-VII combined (Fig. 1J).

Pronotum. Widest at base, apical angles acute, basal angles obtuse; dorsal surface moderately densely punctate; punctures moderate and large in size. Marginal bead complete, not interrupted basomedially, setose basolaterally.

Scutellar shield. Parabolic, wider than long; base declivous at elytral base; dorsal surface scarcely punctate.

Elytra. Surface punctate with weakly impressed striae; interstriae with strong transverse wrinkles; punctures moderate to dense, small to moderate in size, lacking setae; elytral base with dimple lateral of scutellar shield; humeral umbone with prominent tubercle; sides behind humeral umbone narrowed, with lateral margins projected externally; surface rugose; elytral apex rounded, with lateral tubercles moderately developed; sutural apex obtuse, angular (Figs 2A, F-H).

Propygidium. Concealed beneath elytra.

Pygidium. Subtriangular, twice as wide as long; finely, densely rugose. Margins beaded with sparse, moderately long setae. Apex truncate in male and rounded in female.

Venter (Fig. 2B). Prosternal process elongate, projecting vertically with respect to ventral plane; apex produced to level of protrochanter, rounded; mesoventral process moderately elevated, not exceeding anterior margin of mesocoxa. Abdominal ventrites I-IV subequal in length in both sexes, ventrite $\mathrm{V}$ about 1.8-2.0 times the length of ventrite IV, ventrite VI subequal in length to ventrite IV (male) or longer than ventrite V (female). Apical ventrite with surface smooth (male) or rugose (female).

Legs. Protibia with three external teeth unequally separated (Figs 2A, F); spur present, subapical. Protarsomere $\mathrm{V}$ of male and female longer than protarsomeres I-IV combined (Fig. 1I). Claws simple in both sexes; inner protarsal claw larger than outer claw (male); outer claw of mesotarsal and metatarsal claws slightly longer and wider than inner claw (both sexes); unguitractor plate laterally flattened, almost the same length as external claw. Male protarsomeres III-V with striate region at ventral apex, lacking in female. Metatibia with sides subparallel, weakly divergent towards apex; external edge with two strong carinae (more robust in female); inner apex with two spurs; inner apex with 9-11 spinulae.

Male genitalia (Figs 1G-H; 2 D-E, I). Parameres 1.5 times shorter than length of phallobase (lateral view). Parameres fused dorsoventrally, symmetrical, with apex split (frontal view), variable in shape (Figs 3A-D).

Female genitalia. Not diagnosed.

Natural history. The only species occurs in arid, semiarid, and tropical environments of Peru from elevations between 400-3.200 m. Adults likely feed on plant foliage, but no specific host has been recorded. Larvae are not known but likely feed on roots or decaying plant material.

Catoclastus specimens are rarely collected, and there are very few specimens available in entomological collections. Etymology. From the Greek 'Cato': under, 'clastus': broken. The name refers to the concavity present in the anterior half of the labium. The gender is masculine.

Composition and distribution. Based on this research, the genus includes only one species that is distributed in Peru (Ayacucho, Cusco, La Libertad, Lima and Loreto departments) (Fig. 3). This distribution corresponds to the Desert and Ucayali biogeographic provinces (MorRONE 2014). The erroneous record from Chile (see Moore et al. 2017 for explanation) was repeatedly cited by subsequent authors (BlackWELder 1944; OHAus 1918, 1934, 1952; Martínez 1971; MachatschKe 1972; KraJCIK 2007; Soula 2010). At the time of the original description, the distribution of specimens originating from Chile and Peru were regularly confused (see comments in SMITH 2002).

\section{Catoclastus chevrolatii Solier, 1851}

(Figs 1A-J, 2A-I)

Catoclastus chevrolatii Solier, 1851: 96-97 (original description).

Catoclastus chevrolati: HAROLD (1869): 1226 (incorrect subsequent spelling).

Catoclastus jaumesi Soula, 2010: 6 (original description), syn. nov.

Type material examined. Catoclastus chevrolatii Solier, 1851: NEOTYPE: (MNHN), labeled: a) 'chevrolati / Chili Solier' [white label handwritten]; b) 'Neotype 2010 / Catoclastus / chevrolati / Solier Soula det.' [red label typeset and handwritten]; c) 'MNHN / EC7026' [white label typeset].

Catoclastus jaumesi Soula, 2010: HоLOTYPE: (CCECL), labeled: a) 'Matucana; Pérou / 2000m; II/2002' [typeset white label]; b) 'Holotype / Catoclastus / jaumesi S. / 2010 Soula' [red label typeset and handwritten]. Allotype: 9 (CCECL), labeled: a) 'Matucana; Pérou / 2000m; II/2002' [typeset white label]; b) 'Allotype / Catoclastus / jaumesi S. / 2010 Soula' [red label typeset and handwritten].

Additional material examined. PERU: LoRETo (1): Yurimarguas, Río Huallaga, III-1997, 500 m (1 MSPC). LiMA (8): Atocongo (cerca de Lima), IX-1946 (1 MUSM); Callahuanca, IV-1976, R. García (1 MUSM); Chaute (Cocachacra), 2500 msnm, 15-III-1990, P. Hocking (1 MUSM); Surco, Peru (1 BMNH); Matucana (2 VMDC); Ferrogas Canyon, Lima (2 USNM). Ayacucho (4): Ocaña, 3200 msnm, 7-II-1969 (1 MUSM), 25-III-1969, P. Hocking (3 MUSM). Cusco (1): Valle Río Apurimac, XI-2011 (1 MSPC).

Non-examined material. PERU: LA LiBertad: Pacasmayo (Ohaus 1918, 1934, 1952). Ayacucho: Ocaña, 6-IV-1936 (Ohaus 1952).

Diagnosis. Body dorsally metallic green, venter coppery green; legs reddish-brown (Figs $2 \mathrm{~A}-\mathrm{C}, \mathrm{F}-\mathrm{H}$ ); head subtrapezoidal, with clypeal margins not reflexed; frontoclypeal suture not impressed; mandibles with two large, rounded, reflexed teeth (Figs 1B, 2A, G); labium hexagonal to semicircular, concave in anterior half(Fig. 1G). Pronotum with marginal bead complete. Elytron with weakly impressed 

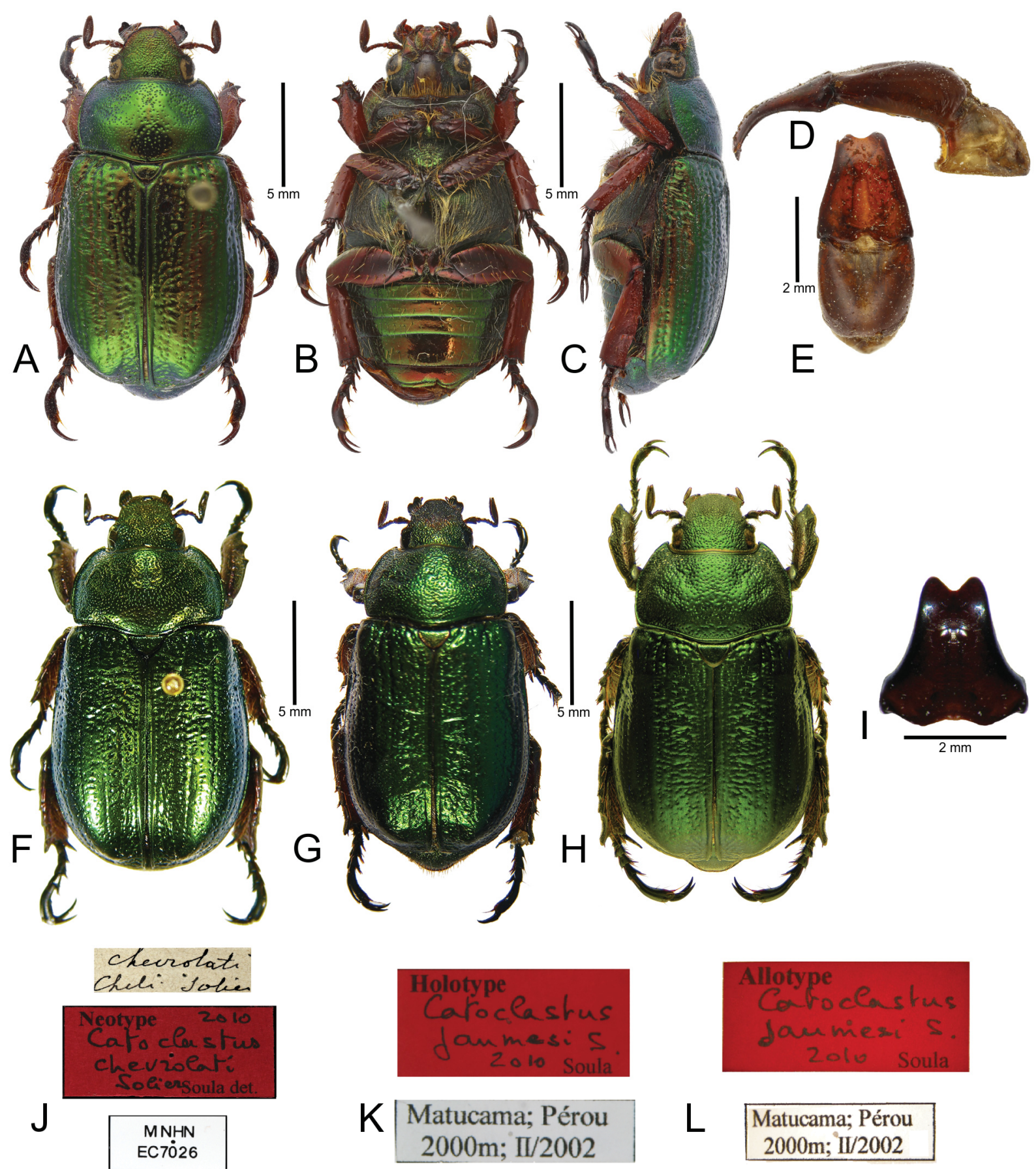

Fig. 2. Morphology of Catoclastus Solier, 1851. A-C - neotype of C. chevrolatii Solier, 1851 (dorsal, ventral and lateral habitus); D-E - parameres, lateral and dorsal view; $\mathrm{F}$ - holotype of $C$. jaumesi Soula, 2010 (dorsal habitus); $\mathrm{G}$ - allotype of $C$. jaumesi (dorsal habitus); $\mathrm{H}$ - female of $C$. chevrolatii (dorsal habitus); I - parameres, frontal view; J-L - type specimen labels (neotype, holotype, and allotype labels).

striae, interstriae with strong transverse wrinkles; elytral base with dimple lateral of scutellar shield (Figs 2A, F). Humeral and apical umbones with prominent tubercles; sides behind humeral umbone narrowed, with margins projected externally. Claws simple on all legs (not toothed). Parameres symmetrical, fused dorsoventrally, with apex split (frontal view) (Figs 2D-E, I).

Comments. Catoclastus chevrolatii exhibit a strong intraspecific variation, represented mainly in the form of the parameres and pronotal sculpture. This variation has caused confusion with respect to the species' identity. Within related ruteline scarabs, HARDY (1975) considered species to be of 'variable entities', and he allowed for intraspecific variation in coloration and even the form of male genitalia in some species of Pelidnota. In contrast, Soula's species concept did not allow for intraspecific variation of species (Moore et al. 2017). In Soula's works, slight differences in color, punctation, or form of male parameres resulted into new species and subspecies without considering the morphological variations and sexual dimorphism. Furthermore, Soula's ruteline species were often based on a small number of specimens (generally one or two) and often 


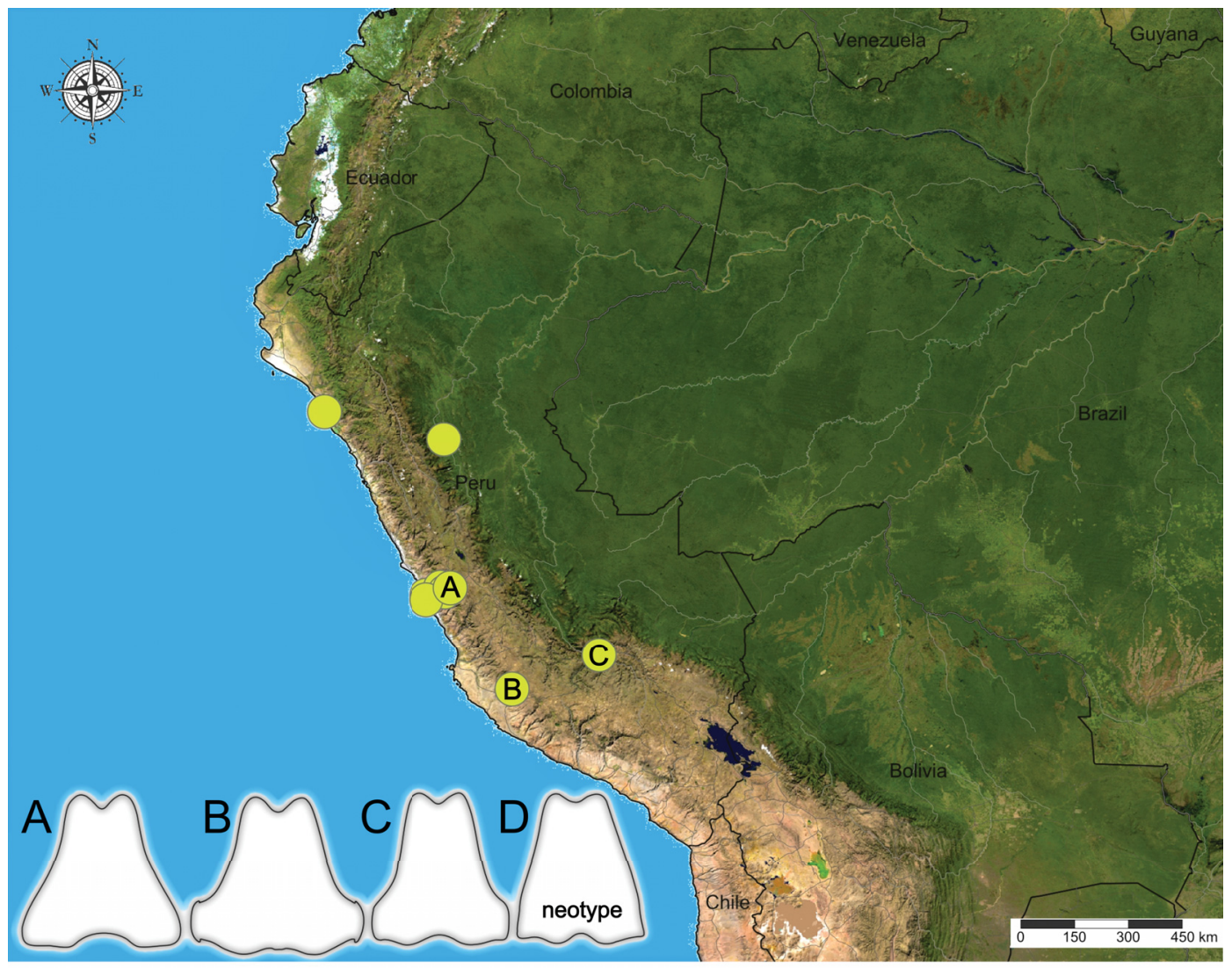

Fig. 3. Distribution of Catoclastus chevrolatii Solier, 1851 with paramere shape variation by locality. A - specimen from Lima (Matucana); B - specimen from Ocaña (Ayacucho); C - specimen from Cusco (Río Apurimac); D - neotype specimen from 'Chile' (erroneous locality).

based on one sex only. New species or subspecies were routinely named from the same population and collecting event (e.g., Soula 2010).

The case of $C$. chevrolatii and $C$. jaumesi is one of many in which Soula indiscriminately described new species and subspecies without considering the natural morphological variation of a taxon, thus generating taxonomic and nomenclature problems that persist until today; these were partly resolved by MOORE \& JAMESON (2013) and MoORE et al. (2017).

Natural history. Adults specimens have been collected from 400-3200 m. Collecting circumstances are unknown, but specimens are likely collected at light in forested areas. Temporal data of collected specimens are as follows: February (3), March (5), April (2), September (1), November (1).

Distribution. Peru: Ayacucho, Cusco, La Libertad, Lima and Loreto departments (Fig. 4).

\section{Species excluded from the genus Catoclastus}

\section{Mecopelidnota rabinovichi (Martínez, 1971) comb. nov. \\ (Figs 4A-D)}

Catoclastus rabinovichi Martínez, 1971: 79-82 (original description).

Type material examined. HоLотуре: $\curvearrowright$ (MACN), labeled: a) 'HOLOTYPUS' [red typeset label]; b) 'PERU / D ${ }^{\circ} \mathrm{CUZCO} \mathrm{/} \mathrm{Ollantaytambo} \mathrm{/}$ Nov: 952 / F. Monrós. leg- / Coll. Martínez’ [beige handwritten label]; c) 'Catoclastus / rabinovichi /sp. nov. / A. MARTÍNEZ-DET. 1970' [red handwritten and typeset label]; d) 'MACN-En / 1432'.

Diagnosis. Mecopelidnota rabinovichi is distinguished from all other Mecopelidnota Bates, 1904 by the symmetrical parameres that lack ventral projections (asymmetrical parameres with ventral projections in M. arrowi Bates, 1904, M. cylindrica (Waterhouse, 1876) and M. marxi Soula, 2008). Additionally, Mecopelidnota rabinovichi is distinguished from other Mecopelidnota species by the apices of parameres widely rounded and diverging laterally leaving a wide gap between them (apices of parameres pointed with a narrow gap between them in $M$. gerardi Soula, 2008, $M$. dewynteri Soula, 2008, M. witti Ohaus, 1913 and M. mezai Soula, 2008). The aedeagus of M. obscura (Taschenberg, 1870) remains undescribed, but the species is likely endemic to Colombia and Ecuador and does not overlap with the distribution of $M$. rabinovichi.

Comments to classification. The habitus of Catoclastus rabinovichi matches that of Mecopelidnota rather than the type species of Catoclastus. The large eyes with an interocular width of 2.3 transverse eye diameters (ca. 2-3x in Mecopelidnota; $4.7 \times$ in Catoclastus), the finely punctured head, pronotum and elytra (rugosely punctured in Catoclastus) and the compact head (more elongated in Catoclastus) support the placement in Mecopelidnota. A semicircular notch at the base of the metatibia was suggested as a diagnostic character for Mecopelidnota but never evaluated for all species of the genus (Moore et al. 2017). The holotype of Catoclastus rabinovichi lacks that character and a detailed species-level analysis of Mecopelidnota will be required to confirm 


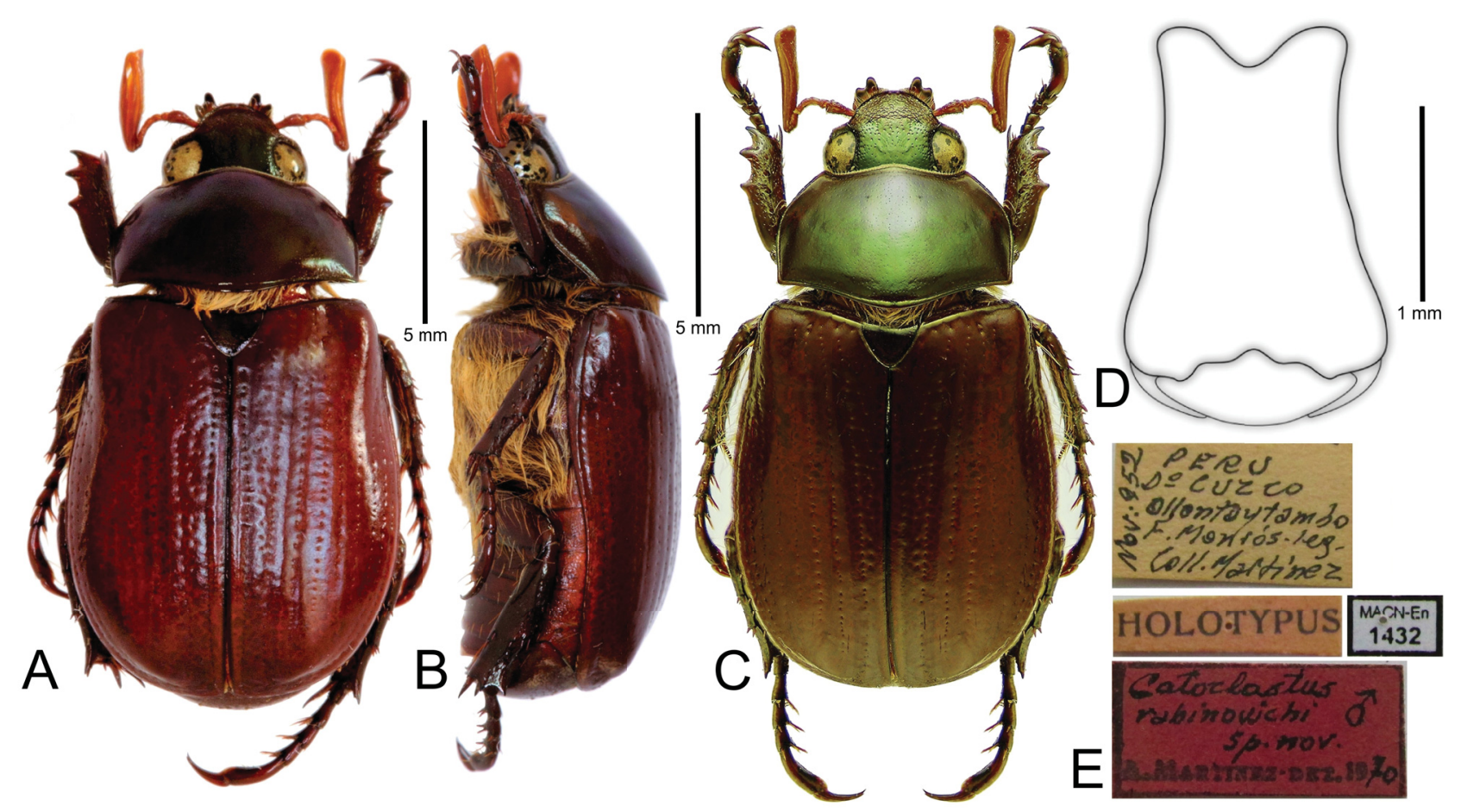

Fig. 4. Morphology of Mecopelidnota rabinovichi (Martínez, 1971). A-B - holotype of Catoclastus rabinovichi (dorsal and lateral habitus). C - male specimen (dorsal view). D - parameres (holotype, frontal view). E - holotype labels.

the importance of this character for the generic attribution. Furthermore, the poorly resolved genus level systematics of 'pelidnotine' leaf chafers and the lack of a phylogenetic framework do not allow us to rule out that a new genus will need to be established for C. rabinovichi.

As a result of this transfer, the genus Mecopelidnota is now composed of nine valid species that are distributed in Colombia, Ecuador, and Peru (Moore et al. 2017).

Distribution. Peru: Cusco department (Ollantaytambo, $3500 \mathrm{~m})$.

\section{Acknowledgments}

We thank the curators of the collections consulted for all facilities granted. We especially appreciate the collaboration of Luis Figueroa (MUSM), Cedric Audibert (CCECL), Beulah Garner (BMNH), and Arturo Roig-Alsina (MACN) for the loan of specimens that are under their care and thank Marcelo Guerrero (Chile) for providing the photographs that illustrate this work. We also thank Antoine Mantilleri (MNHN) for the photographs of the neotype of C. chevrolatii. We extend our thanks to Aleš Bezděk (Biology Centre of the Czech Academy of Sciences, Institute of Entomology, České Budějovice, Czech Republic) for providing valuable literature and Mary Liz Jameson (Wichita State University, Wichita, Kansas, USA) for providing additional specimen data. We appreciate the valuable comments and suggestions made by Andrew Smith (Canadian Museum of Nature, Ottawa, Ontario, Canada) and the anonymous reviewers. The work of MS was supported by the Ministry of Culture of the Czech Republic (DKRVO 2019-2023/5.I.a, National Museum, 00023272).

\section{References}

BLACKWELDER R. E. 1944: Checklist of the coleopterous insects of Mexico, Central America, the West Indies, and South America, part 2. Bulletin of the United States National Museum 185: 189-341.

HARDY A. R. 1975: A revision of the genus Pelidnota of America north of Panama (Coleoptera: Scarabaeidae: Rutelinae). University of $\mathrm{Ca}$ lifornia Publications in Entomology 78: 1-43.

HAROLD E. von 1869: Scarabaeidae. Pp. 979-1346. In: GEMMINGER M. \& HAROLD E. vON (eds): Catalogus Coleopterorum Hucusque Descriptorum Synonymicus et Systematicus, Tom. 4. E. H. Gummi, Munich, Germany, 1346 pp.

KRAJCIK M. 2007: Checklist of the Scarabaeoidea of the World. 2. Rutelinae (Coleoptera: Scarabaeidae: Rutelinae). Second edition. Animma.X, Supplement 4: 1-142.

KRAJCIK M. 2012: Checklist of the world Scarabaeoidea. Animma.X, Supplement 5: 1-278.

LACORDAIRE J. T. 1855: Histoire naturelle de insectes. Genera des coléoptères ou exposé méthodique et critique de tous les genres proposés jusqu'ici dans cet ordre d'insectes. Contenant les familles de pectinicornes et lamellicornes, Volume 3. Librairie Encyclopédique de Roret, Paris, France, 594 pp.

MACHATSCHKE J. W. 1972: Scarabaeoidea: Melolonthidae, Rutelinae. Coleopterorum Catalogus Supplementa 66: 1-361.

MARTÍNEZ A. 1971: Una nueva especie de Catoclastus Solier (Col. Scarab. Rutel. Pelidnotina). Neotropica 17: 79-82.

MOORE M. R. \& JAMESON M. L. 2013: Taxonomic and nomenclatural changes in the Pelidnotine scarabs (Coleoptera: Scarabaeidae: Rutelinae: Rutelini). Coleopterists Bulletin 67: 377-388.

MOORE M. R., JAMESON M. L., GARNER B. H., AUDIBERT C., SMITH A. B. T. \& SEIDEL M. 2017: Synopsis of the pelidnotine scarabs (Coleoptera, Scarabaeidae, Rutelinae, Rutelini) and annotated catalogue of the species and subspecies. ZooKeys 666: 1-349.

MORRONE J. J. 2014: Biogeographical regionalisation of the Neotropical region. Zootaxa 3782: 1-110.

OHAUS F. 1918: Pars 66. Scarabaeidae: Euchirinae, Phaenomerinae, Rutelinae. In: SCHENKLING S. (ed.): Coleopterorum Catalogus, Volumen XX. Berlin, Junk, 241 pp.

OHAUS F. 1934: Coleoptera lamellicornia, Fam. Scarabaeidae, Subfam. 
Rutelinae. T.1: Tribus Rutelini. Genera Insectorum 199A: 1-172. OHAUS F. 1952: Rutelinae (Col. Scarab.). Pp. 1-10. In: TITSCHACK E. (ed.): Beiträge zur Fauna Perus. Gustav Fischer, Jena, 10 pp.

RATCLIFFE B. C., JAMESON M. L., FIGUEROA L., CAVE R. D., PAULSEN M. J., CANO E. B., BEZA-BEZA C., JIMENEZ-FERBANS L. \& REYES-CASTILLO P. 2015: Beetles (Coleoptera) of Peru: A survey of the families. Scarabaeoidea. Journal of the Kansas Entomological Society 88: 186-207.

PHILIPPI F. 1887: Catálogo de los coleópteros de Chile. Anales de la Universidad de Chile 71: 619-806.

REED E. C. 1876: Catálogo de los coleópteros de Chile (segunda parte). Anales de la Universidad de Chile 48: 274-295.

SEIDEL M., JAMESON M. L. \& STONE R. L. 2017: A new cryptic species and review of the east-Andean leaf chafer genus Mesomerodon Ohaus, 1905 (Coleoptera, Scarabaeidae, Rutelinae). ZooKeys 671: $61-85$.

SMITH A. B. T. 2002: Revision of the southern South American endemic genus Aulacopalpus Guérin-Méneville with phylogenetic and biogeographic analyses of the subtribe Brachysternina (Coleoptera:
Scarabaeidae: Rutelinae: Anoplognathini). Coleopterists Bulletin 56: $379-438$.

SOLIER A. J. J. 1851: Zoologia: Coleopteros. In: GAY C. (ed.): Historia física y política de Chile según documentos adquiridos en esta república durante doce años de residencia en ella Paris. Zoología 5: 1-285.

SOULA M. 2008: Les coléoptères du nouveau monde. Volume 2: Rutelini 2. Révision des Pelidnotina 2. Révision des genres: Parhoplognathus, Chipita n. gen., Heteropelidnota, Homothermon, Hoplopelidnota, Mesomerodon, Mecopelidnota, Patatra n. gen. (Coleoptera: Scarabaeidae, Rutelinae, Rutelini). Besoiro: Supplément au Bulletin de liaison de 1'Association Entomologique pour la Connaissance de la Faune Tropicale. AECFT, Saintry, 40 pp.

SOULA M. 2010: Les coléoptères du nouveau monde. Volume 4: Rutelini 4. Révision des Pelidnotina 4. Une révision des genres Catoclastus, Homonyx. Retour sur quelques espèces ou groupe d'espèces de Pelidnota. Addenda 2010 (Coleoptera: Scarabaeidae: Rutelinae: Rutelini: Pelidnotina). Besoiro: Supplément au Bulletin de liaison de l'Association Entomologique pour la Connaissance de la Faune Tropicale. AECFT, Saintry, 66 pp. 
